Environment Conservation Journal 19 (3)119-121, 2018

ISSN 0972-3099 (Print) 2278-5124 (Online)

Abstracted and Indexed

\title{
Role of Panchakarma and Yoga in treatment of obesity
}

\author{
Joshi Rashmi, Kaushik Bhanupriya网, Pandey Shikha and Sharma Uttam Kumar
}

Received: 20.04.2018

Revised: 28.06.2018

Accepted: 10.10.2018

\begin{abstract}
Obesity is a condition in which body has excess fat which shows negative effects on the body. The incidences of obesity have been regularly increasing. It is also including childhood obesity. At an individual level, a combination of excessive food energy intake and a lack of physical activity is thought to explain most cases of obesity It is not only a disease increases the body fat but also includes other health related disorders i.e; Breathing disorder, Heart disease, Depression, Diabetes mellitus, High blood pressure, High cholesterol etc. In Ayurveda obesity is considered as stholya, means a person in whom excessive and abnormal increase of Meda along with Mamsa Dhatu in the body, which results into pendulous appearance of Sphika, Udara and Stana. Obesity management has been described in many places in Ayurveda. In Panchkarma obesity is treated through Lekhan basti, Vamana, Virechana, Udvartan etc. Lekahan basti and Udvartan plays a very important role in obesity management. Yogic management of obesity is based on controlled and balanced diet, Yoga postures or Asanas and breathing techniques. Consuming only the amount of food that we really need, along with regular exercise, performing intermittent water fasts, Pranayama, and Yogaasanas can give relief to obesity. Although Yoga and Panchakarma have almost same in respect of Shodhana procedures.
\end{abstract}

Key words: Obesity, depression, panchkarma, Pranayama.

\section{Introduction}

Obesity is a medical condition in which excess body fat has accumulated and shows its negative effect on health. In Ayurveda obesity is considered as stholya, means a person in whom excessive and abnormal increase of Meda along with Mamsa Dhatu in the body, which results into pendulous appearance of Sphika, Udara and Stana (Charak Samhita, 2012). The increased bulk is not matched by a corresponding increase in energy. In Ayurvedic literature, systematic classification of the disease Sthaulya is not available. Vagbhatta has mentioned three types of Sthaulya while describing the efficacy of Langhana therapy (AH.Su.14/1214)(Astang Hridaya, 2010) as given below -

$>$ Hina Sthaulya: Mild degree of overweight.

$>$ Madhyama Sthaulya: Moderate degree of overweight.

$>$ Ati Sthaulya: Excessive state of overweight.

WHO had used Body mass index (BMI) to define obesity.

Author's Address

Department of Panchakarma, Uttarakhand Ayurved University, Gurukul Campus, Haridwar

E-mail.: dr.bhanupriyakaushik22@gmail.com
BMI $=$ Weight in kilograms $/$ height in meters ${ }^{2}$ Particular bodies have made some modifications to the WHO definitions.

$>$ BMI 35 or 40 is severe obesity.

$>$ BMI $40-44.9$ or 49.9 is morbid obesity.

$>\mathrm{BMI}$ of 45 or 50 is super obese.

\section{Etiological Factors}

According to Ayurveda, the central cause of almost all diseases is the vitiation of waste products (Malas- the end products of Dhatus) and opines that "Sarvesham Cha Roganam Nidanam Kupitah Malah" which is outcome of fault of different sets of Agni i.e. Jatharagni, Dhatvagni, Bhootagni and Pachakamsha. By virtue of these substances, the functional activity of body humors (Doshas) deranged, which may leads to play an important role in the genesis of diseases. This is due to faulty regimens of foods, food habits and lifestyle errors along with genetic abnormality. Sushruta has considered that Rasa Dhathu is the main culprit for both obesity and emaciation- Rasa Nimittameva Sthaulyam Karshyam Cha (Susrutha Samhita, 2012). Both Ayurveda and conventional system of medicine have considered. 
At an individual level, a combination of excessive food energy intake and a lack of physical activity is thought to explain most cases of obesity. Some common causes are- genetics, medical reasons, psychiatric illness, easily accessible and palatable diet, increased reliance on cars, insufficient sleep, endocrine disruptors, pregnancy, excess food taking, sedentary lifestyle.

Symptoms and Complications

$>$ Breathing disorder(e.g. sleep apnea, chronic obstructive pulmonary disease)

$>$ Certain types of cancers(prostate and bowel cancer in men, breast \& uterine cancer in women)

$>$ Heart disease

$>$ Depression

$>$ Diabetes mellitus 2

$>$ Gall bladder or liver disease

$>$ High blood pressure

$>$ High cholesterol

$>$ Joint disease (Davidson)

\section{$>$}

Management through panchakarma

Obesity management has been described in many places in Ayurveda. In Panchkarma obesity is treated through Lekhan basti, Vamana, Virechana, Udvartan etc. Lekahan basti and Udvartan plays a very important role in obesity management.

Lekhanbasti: Itis a type of enema (given through the ano-rectal route) which contains Ayurvedic drugs which cause the excoriation of the excessive fat from the body. The drugs which are used in the preparation of Lekhan basti are Triphala decoction, honey, Gomutra, Saindhavsalt ,Hing, Yavakshar, Kasis, Shilajat which are all fat-reducing by virtue of their properties etc(Charak Samhita).Lekhan basti given through the anal route goes into the intestine and from there the active properties of the Basti spread into the whole body. This therapy causes the reduction of excessive fat from all over the body right from the top to the bottom.

Udvartana: The most common Ayurvedic treatment used in for losing weight is the treatment of Udvartana, where we use herbal powders (in form of oils or dry powders) which are dry \& rough in nature \& hot in potency.The oil taken for Udvartana, is sesame based which is hot in potency and is infused with herbs which create lightness, dryness, roughness, remove the blockages \& stiffness, and also have a 'cutting or liquefying action' on the fat tissue. This oil also takes care that the skin does not become dry superficially \& remains soft \& supple after the treatment.This herbal paste (powders \& oils) when rubbed on the body in a specific manner creates friction, which open the pores, remove blockages in vessels, increase the heat in the tissues \& percolates inside to stimulate fat metabolism.

Management through Yoga: Yogic management of obesity is based on controlled and balanced diet, Yoga postures or Asanas and breathing techniques. Consuming only the amount of food that we really need, along with regular exercise, performing intermittent water fasts, Pranayama, and Yogaasanas can give relief to overweight and obese people. It is said in the yogic text 'Hatha Yoga Pradeepika' and others that practice of pranayama make the body slim and fit (Swami Svatmarama). Pranayama can help to burn excessive fat in the body. There are two pranayama practices that are good for weight reduction Kapalabhati and Anulom Vilom Pranayama.

Kapalabhati or the skull cleansing breath involves forceful exhalation and normal inhalation. This is done in a comfortable sitting posture with erect spine. The belly is drawn in with every forceful exhalation and filled again with normal inhalation. This is known to reduce the fat around the belly.

Anulom Vilom Pranayama or the alternate nostril breathing technique also helps to reduce weight. This Pranayama is said to generate heat in the body and to burn down excessive fat.

Here are some effective Yoga Asanas that helps in obesity-

\section{Lying down Asanas:}

\section{Nauka Asana}

Nauka asana or boat pose helps reduce fat on your midriff, tones your abdominal muscles and strengthens your back.

\section{Pawanmukt Asana}

Pawanmukt asana is also known as the wind releasing pose. It helps in burning cellulose in your thighs, hips and abdominal region.

\section{Bhujang Asana}

Bhujang asana is also called the cobra pose. It helps in stretching and toning the muscles of your arms, shoulders, buttocks, thighs, back and abdomen. Bhujang asana is the best way to reduce belly fat. It gives a good stretch to your abdominal 
muscles and helps you attain a flat belly with regular practice.

\section{Sitting Asanas}

4. Ushtra Asana

Ushtra asana or the camel pose is another pose that is beneficial in reducing fat in your tummy area. It also helps tone your back, chest and shoulder muscles.

\section{Paschimottan Asana}

Paschimottan asana is also known as the forward seated bend. It is a beneficial yoga asana for countering obesity.It helps in reducing fat and toning your abdominal area, pelvic region, thighs, hips and shoulders.

\section{Titli Asana}

Titli asana is also known as butterfly pose. It strengthens and tones your hip and thigh muscles and joints. It is very effective in reducing the fat around your hips and thigh region.

\section{Standing Asanas}

\section{ArdhChakrasana}

This asana is also known as standing backward bend. It helps tone the muscles of your upper body that includes your arms, shoulders, chest and upper body.

\section{ParshvaKonasana}

This asana is also known as side angle stretch. It helps stretch your muscles and helps improve your body shape. It involves all the muscles in your body. It is especially beneficial for reducing fat on your thighs, hips, pelvic and waist area.

9. Veerbhadra Asana

Veerbhadra asana is also known as the warrior pose. It helps enhance your valour, body balance and grace. It strengthens and burns fat in your arms, thighs, legs and lower back area.

\section{Garud Asana}

Garud asana is also known as the eagle pose. It helps enhance your body balance. It is beneficial for reducing excess fat on your upper back, arms, shoulders and outer thighs (https://nirogam.com).
Neti, Dhoti, Kunjal etc burns the calories enhances the basal metabolic rate and improves the circulation, these effects on body helps to reduce body fat. The different oil applications performed in Panchakarma helps to remove the fat from tissue and make them compact and firm and the objective of Yoga is also to make the body slim and compact. Pranayaam not only improves the respiratory system and blood circulation but also helps to reduce the belly fat due to the exertion of the abdominal muscles. The Basti karma practised in Panchakarma helps to clean the intestine and helps to remove nearby deposited fat. If the Yoga and Panchakarma are used collaboratively in the management of obesity,the results are very effective and encouraging.

\section{Conclusion}

Although, Yoga and Panchakarma have almost same in respect of Shodhana procedures. As in yoga Kunjan kriya,Sankhprakshalna and Basti are advised,in Panchakarma Vamana, Virechana and Basti are advised for Shodhana.

\section{References}

Shukla Vidhyadhar, 2012 .Charak Samhita:- Purvardh, Varanasi, Chaukhamba Surbharti Prakashan.

Tripathi Brahmanand, 2010. Astang Hridaya, Chaukhamba Surbharati Prakashan.

Shastri Ambika dutt, 2012. Susrutha Samhita: - Purvardh, Varanasi, Chaukhamba Surbharti Prakashan.

Davidson. Principal \& practice of medicine, $20^{\text {th }}$ Edision.

Shukla Vidhyadhar, 2012. Charak Samhita: - Purvardh, Varanasi, Chaukhamba Surbharti Prakashan.

Svatmarama, Swami. Hath yoga pradipika

https://nirogam.com

\section{Discussion}

The purificatory procedures of Panchakarma removes the waste and toxins from the body, along with this process the level of body fluids, water, lipids deposited that get reduced in some extent.The different practices of Yoga i.e; Asanas, Pranayaam, 